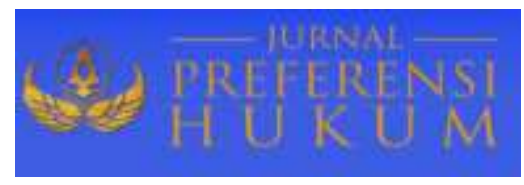

Jurnal Preferensi Hukum | ISSN: 2746-5039

Vol. 2, No. 2 - Juli 2021, Hal. 349-353| Available online at https://www.ejournal.warmadewa.ac.id/index.php/juprehum

DOI: https://doi.org/0.22225/jph.2.2.3334.349-353

\title{
PENYELESAIAN WANPRESTASI ATAS DASAR FORCE MAJEUREAKIBAT PANDEMI COVID-19 DALAM PERJANJIAN PEMBIAYAAN KONSUMEN
}

\begin{abstract}
Abstrak
Consumer finance adalah salah satu lembaga pembiayaan yang secara resmi masih tergolong baru di Indonesia. Perjanjian pembiayaan konsumen merupakan perjanjian yang timbul dalam praktik sehari-hari masyarakat luas. Dalam suatu hubungan kontraktual pandemi Covid-19 menjadi titik perdebatan antara pelaku usaha yang terikat dalam kontrak tersebut. Pihak debitur yang memiliki kewajiban kontraktual menjadikan keadaan pandemi Covid-19 sebagai dasar untuk membebaskan diri dari kewajibannya memenuhi prestasi. Tujuan dari penelitian ini adalah untuk mengetahui dasar hukum pengaturan perjanjian pembiayaan konsumen dalam perspektif hukum kontrak dan mengetahui akibat hukum force majeure bagi para pihak pada perjanjian pembiayaan konsumen dalam hal terjadi pandemi Covid-19. Adapun masalah yang terdapat dalam penelitian ini adalah bagaimanakah dasar hukum pengaturan perjanjian pembiayaan konsumen dalam perspektif hukum kontrak serta bagaimanakah akibat hukum force majeure bagi para pihak pada consumer finance agreement dalam ketika terjadinya wabah virus corona. Metode yang digunakan adalah metode penelitian yang bersifat normatif dengan mana memakai pendekatan undang-undang dan pendekatan secara konseptual. Berdasarkan hasil penelitian ini dapat disimpulkan bahwa pandemi Covid-19 yang terjadi saat ini hanya dapat dikualifikasikan sebagai keadaan memaksa yang bersifat tidak mutlak atau relative atau dapat dikatakan bahwa debitur tidak dapat menjadikan alasan pandemi ini sebagai alasan pembatalan kontrak. Keadaan memaksa yang bersifat relatif tersebut hanya sebatas menunda pelaksanaan kewajiban memenuhi prestasi untuk sementara waktu dimana para pihak dapat melakukan negosiasi terhadap perjanjian yang telah dibuat sebelumnya.
\end{abstract}

Made Bagus Rizal Raysando, Ni Komang Arini Setyawati, Desak Gde Dwi Arini

Fakultas Hukum, Universitas Warmadewa, Denpasar-Bali, Indonesia

kadekraysa8@gmail.com, arinistyawati@gmail.com, arini.gede@gmail.com

Kata Kunci: Covid-19, Force majeure, Perjanjian, Pembiayaan konsumen.

\begin{abstract}
Consumer finance is a financing institution that is officially still relatively new in Indonesia. Consumer financing agreements are agreements that arise in the day-to-day practice of the wider community. In a contractual relationship, the Covid-19 pandemic has become a point of debate between business actors who are bound by the contract. Debtors who have contractual obligations make the Covid-19 pandemic a basis for freeing themselves from their obligations to fulfill achievements. The purpose of this research is to find out the legal basis for the arrangement of consumer financing agreements in the perspective of contract law and to find out the consequences of force majeure for the parties to the consumer financing agreement in the event of a Covid-19 pandemic. The problems contained in this research are how the legal basis for the regulation of consumer financing agreements in the perspective of contract law and what are the consequences of force majeure for parties to the consumer finance agreement in the event of a corona virus outbreak. The method used is a normative research method by using a statutory approach and a conceptual approach. Based on the results of this study, it can be concluded that the Covid-19 pandemic currently occurring can only qualify as a forced condition which is not absolute or relative or it can be said that the debtor cannot make the reason for this pandemic as a reason for contract cancellation. This relative coercion is limited to delaying the implementation of the obligation to fulfill the achievement for a while, whereby the parties can negotiate the agreements that have been previously made.
\end{abstract}

Keywords: Covid-19, Force majeure, Agreement, consumer financing.

\section{PENDAHULUAN}

Ekonomi memainkan peran penting dalam kehidupan masyarakat yang mana kita ketahui kehidupan manusia akan selalu berkaitan dengan kebutuhan ekonomi. Eksistensi dari ekonomi memberikan kesempatan kepada manusia untuk dapat memenuhi kebutuhan hidupnya baik itu kebutuhan primer, 
sekunder maupun tersier. Untuk itu dapat disimpulkan ekonomi merupakan bagian penting dalam kehidupan manusia sehingga perlu adanya suatu aturan yuridis dalam mengatur mengenai pelaksanaan dalam sistem perekonomian khususnya di Indonesia.

Perjanjian atau kontrak merupakan sebuah upaya dari manusia untuk memenuhi berbagai kepentingan dalam pemenuhan pergaulan hidupnya, baik yang berskala besar maupun kecil. Tidak disadari bahwa dalam kehidupan sehari-hari, perjanjian atau kontrak dilakukan oleh setiap manusia, baik dalam bentuk lisan maupun tertulis. Perjanjian yang dibuat oleh para pihak khususnya dibidang ekonomi tidak dapat dilepaskan dari peran hukum. Hukum telah memberikan wadah bagi setiap kegiatan yang dilakukan manusia dalam kehidupannya (Johannes Ibrahim Kosasih, 2019:16).

Dalam suatu perikatan yang melahirkan hubungan kontraktual dimana para pihak yang telah bersepakat untuk mengikatkan diri melalui perjanjian yang dibuat maka segala klausul yang tercantum pada perjanjian tersebut harus ditaati oleh para pihak baik kreditur maupun debitur. Salah satu perjanjian yang ada di masyarakat adalah perjanjian pembiayaan konsumen (consumer finance) yang mana merupakan salah satu lembaga pembiayaan yang eksistensinya tergolong masih baru di Indonesia. Consumer financeagreement merupakan perjanjian atau kontrak yang timbul dalam praktik sehari-hari masyarakat luas. Perlu diketahui bahwa perjanjian tersebut tidak diatur secara khusus dalam KUHPerdata, akan tetapi dalam prakteknya diperbolehkan oleh KUHPerdata.

Pembiayaan konsumen ini adalah salah satu jasa pembiayaan yang dapat diketahui bersumber dari banyak aturan yuridis baik perjanjian itu sendiri maupun peraturan perundang-undangan yang berlaku. Dari aspek hukum perdata bahwa perjanjian merupakan sumber utama pembiayaan konsumen tersebut dan peraturan perundang-undangan merupakan sumber hukum yang utama pembiayaan konsumen dari perspektif public (Sunaryo, 2009:99).

Dalam praktik bisnis, pandemik Covid-19 menjadi titik perdebatan antara pelaku usaha yang terikat dalam kontrak tersebut. Debitur yang pada dasarnya mempunyai kewajiban dalam suatu kontrak yang telah disepakati, dengan adanya wabah covid-19 ini tidak sedikit yang ingin mengambil kesempatan untuk membebaskan dirinya dalam pemenuhan prestasi dan juga adanya sebagian pelaku-pelaku usaha yang menjadikan dasar bahwa keadaan pandemi sebagai alasan untuk pembatalan kontrak yang sudah disepakati sebelumnya. Adapun bentuk-bentuk dari wanprestasi, yaitu Muhammad Syaifuddin (2012:338):

1. Tidak melaksanakan prestasi sama sekali;

2. Melaksanakan prestasi, tetapi tidak sebagaimana mestinya;

3. Melaksanakan prestasi, tetapi tidak tepat pada waktunya;

4. Melaksanakan perbuatan yang dilarang dalam perjanjian

Perjanjian yang merupakan suatu instrumen yang memiliki unsur adanya hak dan kewajiban tentu dapat diharapkan terjadi secara adil dan baik serta memiliki proporsionalitas sesuai dengan apa yang sudah disepakati bersama. Namun tidak dapat dipungkiri bahwa adanya potensi terjadinya suatu hambatan dalam pelaksanaanya yang bahkan mengakibatkan terjadinya kegagalan berkontrak yang disebabkan oleh faktor baik internal maupun eksternal (Agus Yudha Hernoko, 2010 260).

Penelitian ini telah dilakukan oleh peneliti sebelumnya yang serupa, menurut Yusuf \& Djuwityastuti, (2018) Jaminan yang diatur dalam perundang-undangan di Indonesia objeknya dapat berupa benda bergerak maupun benda tak bergerak, bersifat hak kebendaan sebagaimana diatur dalam Pasal 528 KUHPerdata yang absolut mutlak, dapat dipertahankan terhadap siapapun dan droit de suite yaitu mengikuti benda pada siapapun yang menguasainya. Selain itu juga bersifat accessoir atau ikutan yaitu suatu hak yang hapusnya bergantung pada perjanjian pokoknya, yang biasanya berupa perjanjian pinjam uang, serta adanya hak preferen yaitu hak yang didahulukan pemenuhannya dari piutang lain. Maehaeni\&Emmanuel (2020) Peristiwa pandemi Covid-19 menjadi pembelajaran bahwa perjanjian yang dibuat oleh para pihak khususnya perjanjian baku yang dibuat oleh kreditur (perusahaan pembiayaan dengan pengawasan Otoritas Jasa Keuangan) semestinya mampu menjangkau segala kemungkinan yang akan terjadi di masa depan. Perjanjian baku harus berdasarkan itikad baik dan kepatutan dengan mempertimbangkan keseimbangan kepentingan dan keadilan, sehingga perlu mengantisipasi dengan memasukkan klausul yang berkeadilan. Covid 19 berdampak pada segala aspek kehidupan masyarakat, terutama aspek ekonomi, dimana telah 
terjadi penurunan kemampuan ekonomi seseorang akibat adanya penurunan pendapatan karena sepinya konsumen,akibat berhentinya usahanya karena adanya kebijakan PSBB, atau akibat pemberhentian sementara/PHK, sehingga adanya pandemic Covid yang menyebabkan penurunan ekonomi seseorang banyak mempengaruhi pelaksanaan perjanjian bagi seseorang (Aminah, 2020).

Tujuan dari penelitian ini adalah untuk mengetahui dasar hukum pengaturan perjanjian pembiayaan konsumen dalam perspektif hukum kontrak dan mengetahui akibat hukum force majeure bagi para pihak pada perjanjian pembiayaan konsumen dalam hal terjadi pandemi Covid-19.

\section{METODE PENELITIAN}

Penelitian ini termasuk dalam Jenis penelitian hukum normatif atau biasa dikenal dengan penelitian hukum doktrinal (doktrinal research), yaitu penelitian yang dilakukan dengan cara meneliti bahan pustaka atau data sekunder yang terdiri dari bahan hukum primer, bahan hukum sekunder, dan bahan hukum tersier. Menurut Peter Mahmud Marzuki (2014: 55-56), segala penelitian yang berkaitan dengan hukum (legal research). Pada penelitian hukum normatif ini membahas mengenai penyelesaian wanprestasi atas dasar force majeure akibat pandemi Covid-19 terkait consumer finance agreement dan pada penelitian ini penulis menggunakan metode pendekatan state approach dan Conceptual Approad serta teknik pengumpulan bahan hukum yaitu dilakukan dengan cara menganalisa literatur-literatur yang telah ada ataupun jurnal-jurnal ilmiah terkait yang relevan dengan permasalahan yang akan dibahas pada penelitian ini (Bambang Sunggono, 2015 27).

\section{HASIL DAN PEMBAHASAN}

\section{Dasar Hukum Pengaturan Perjanjian Pembiayaan Konsumen dalam PerspektifHukum Kontrak}

Perjanjian atau yang disebut juga sebagai persetujuan ialah bersumber dari perikatan karena adanya persetujuan dari pihak-pihak yang mengikatkan diri. Dapat disimpulkan bahwa relevansi antara perikatan dan perjanjian tersebut ialah bahwa perjanjian yang disepakati melahirkan suatu perikatan lalu istilah kontrak itu sendiri diartikan lebih sempit mengingat hanya bersifat tertulis (Subekti, 1995).

Pembiayaan konsumen adalah suatu kegiatan dimana dilakukannya pembiayaan oleh perusahaan atau lembaga keuangan non-bank yang dengan kata lain bahwa perusahaan ini bergerak dibidang jasa pembiayaan dalam hal pengadaan barang yang sesuai dengan kebutuhan para konsumen (Sembiring, 2001:114)

Perjanjian pembiayaan konsumen ini tidaklah diatur secara khusus atau spesifik dalam KUHPerdata namun dalam pelaksanaan kegiatan yang dilaksanakan oleh perusahaan pembiayaan terdapat suatu aturan hukum yang dipakai dari aspek hukum perdata yaitu Pasal 1338 KUHPerdata mana pasal tersebut memuat asas kebebasan berkontrak sebagai dasar dalam membuat perjanjian dan perundangundangan dibidang hukum perdata.

Di dalam hal pembuatan kontrak pembiayaan konsumen, Pasal 1320 KUHPerdata digunakan sebagai syarat sahnya sebuah kontrak yang nantinya akan dibuat atas dasar kesepakatan para pihak yang mengikatkan diri dan menyepakati perjanjian tersebut layaknya undang-undang. Kemudian konsekuensi yang harus diterima para pihak yang telah menyepakatinya adalah harus melaksanakan seluruh klausul perjanjian tersebut dengan itikad baik dan tidak mungkin dapat dibatalkan sepihak. Perjanjian yang dibuat secara tertulis tersebut menjadi dasar atau bukti jika dikemudian hari terjadi permasalahan hukum.

Perjanjian pembiayaan konsumen tersebut dapat dimaknai sebagai perjanjian pinjam pakai habis serta perjanjian jual beli bersyarat yang merupakan suatu bentuk perjanjian yang tunduk pada KUHPerdata dan dapat disimpulkan bahwa kedua perjanjian tersebut merupakan sumber hukum utama bagi kontrak pembiayaan konsumen.

\section{Akibat Hukum Force Majeure bagi para Pihak pada Perjanjian Pembiayaan Konsumen dalam Hal Terjadi Pancemi Covid-19}

Adanya wabah covid-19 tersebut mendorong pemerintah untuk membuat berbagai peraturan yang terkait dengan adanya wabah Covid-19 ini salah satu diantaranya yaitu dimana Presiden telah menerbitkan Perpu yang menyangkut tentang stabilitas sistem keuangan dalam hal penanganan wabah virus corona. Perpu 
dapat dibuat oleh Presiden dalam hal terjadi kegentingan memaksa, jadi dapat disimpulkan bahwa wabah Covid-19 yang terjadi saat ini merupakan suatu keadaan memaksa yang mengancam sistem perekonomian dan stabilitas sistem keuangan di Indonesia. Untuk itu dapat dikatakan selain Keppres Nomor 12 Tahun 2020 tentang Penetapan Bencana Non Alam Penyebaran Wabah Coronavirus Disease 2019 (Covid-19) Sebagai Bencana Nasional, Perpu nomor 1 Tahun 2020 tersebut juga relevan untuk dijadikan dasar telah terjadi keadaan memaksa.

Force majeure karena Pandemi Covid-19 tidak serta merta dapat dijadikan sebagai alasan keadaan memaksa karena tidak semua debitur ketika terjadi pandemi ini terhalang untuk melaksanakan kewajiban atau memenuhi prestasinya melainkan tergantung pada sektor usaha yang dijalankan debitur.

Pandemi Covid-19 yang terjadi saat ini hanya dapat dikualifikasikan sebagai keadaan memaksa yang bersifat tidak mutlak atau relative atau dengan kata lain debitur tidak dapat menjadikan alasan pandemi ini sebagai alasan pembatalan kontrak. Keadaan memaksa yang bersifat relatif tersebut hanya sebatas menunda pelaksanaan kewajiban memenuhi prestasi untuk sementara waktu dimana para pihak dapat melakukan negosiasi terhadap perjanjian yang telah dibuat sebelumnya dan hal ini pun didukung dengan adanya Peraturan Otoritas Jasa Keuangan Nomor 14 Tahun 2020 dimana peraturan ini salah satu kententuannya menyangkut tentang restrukturisasi kredit.

Dalam kaitannya dengan perjanjian pembiayaan konsumen, jika debitur tidak dapat melaksanakan kewajiban sebagaimana yang diatur dalam suatu perjanjian, maka debitur dapat mengajukan permohonan kepada kreditur untuk dilakukannya restrukturisasi kredit dengan alasan telah terjadi keadaan memaksa yang menyebabkan usaha atau bisnis si debitur terdampak akibat adanya pandemi covid-19. Namun demikian kreditur juga tetap harus mengedepankan prinsip kehati-hatian dalam mengabulkan permohonan restrukturisasi yang diajukan oleh debitur sesuai dengan syarat-syarat restrukturisasi yang diatur dalam POJK Nomor 14 Tahun 2020 tersebut.

Akibat hukum bagi para pihak jika dikaitkan dengan perjanjian pembiayaan konsumen apabila debitur tidak dapat melaksanakan kewajiban memenuhi prestasinya yaitu kreditur tidak dapat menuntut pelaksanaan kewajiban kepada debitur untuk memenuhi prestasinya namun dengan catatan debitur mampu membuktikan bahwa memang pemenuhan prestasi tersebut tidak dapat dilaksanakan karena terjadi keadaan memaksa. Akibat hukum bagi debitur yaitu dapat menunda pelaksanaan kewajiban tersebut serta tidak wajib untuk membayar bunga ataupun denda akibat keterlambatan pembayaran angsuran kredit tersebut.

\section{SIMPULAN DAN SARAN}

\section{Simpulan}

Kesimpulan dari hasil penelitian ini adalah sebagai berikut:

1. Dasar hukum pengaturan consumer finance agreement dalam perspektif hukum kontrak yaitu bahwa perjanjian ini tidak diatur secara spesifik maupun khusus di dalam ketentuan KUHPerdata namun dalam pelaksanaan kegiatan yang dilakukan perusahaan pembiayaan konsumen terdapat aturan hukum yang digunakan bersifat umum dari segi hukum perdata yaitu Pasal 1320 yang memuat syarat sahnya suatu perjanjian dan Pasal 1338 KUHPerdata yang mana dalam pasal itu memuat asas kebebasan berkontrak sebagai dasar dalam membuat perjanjian dan perundang-undangan dibidang hukum perdata. Perjanjian pembiayaan konsumen dapat dimaknai sebagai perjanjian pinjam pakai habis yang diakomodir dalam Pasal 1754-1773 BW dan perjanjian jual beli bersyarat ditentukan oleh Pasal 1457-1518 BW yang merupakan bentuk perjanjian yang pada prinsipnya tunduk pada ketentuan buku III KUHPerdata bahwa kedua perjanjian tersebut merupakan sumber hukum utama bagi perjanjian pembiayaan konsumen.

2. Akibat Hukum Force majeure bagi para pihak pada perjanjian pembiayaan konsumen dalam hal terjadi pandemi Covid-19 yaitu dapat dijadikan alasan sebagai force majeure yang bersifat relatif yang dapat diartikan sebagai keadaan memaksa yang tidak memiliki dampak mutlak tidak dapat dilaksanakannya suatu perjanjian. Keadaan memaksa yang bersifat relatif tersebut hanya sebatas menunda pelaksanaan kewajiban memenuhi prestasi untuk sementara waktu dimana para pihak dapat melakukan negosiasi terhadap perjanjian yang telah dibuat sebelumnya.

\section{Saran}


Berikut adalah beberapa saran yang penulis berikan untuk arah perkembangan selanjutnya:

1. Kepada Pemerintah dan regulator dalam hal ini OJK agar diharapkan tetap memberikan keringanan tambahan pasca berakhirnya masa restrukturisasi karena mengingat masih akan ada potensi risiko yang timbul yaitu kemampuan debitur untuk membayar hutang masih sulit setelah berakhimya masa restrukturisasi tersebut.

2. Kepada para praktisi hukum khususnya di bidang hukum perdata agar dapat memberikan sosialisasi mengenai pengertian force majeure dalam hal terjadi pandemi Covid-19 sehingga tidak menimbulkan kebingungan di masyarakat yang sedang mengalami permasalahan terkait dengan hubungan kontraktual.

3. Bagi pihak lembaga pembiayaan konsumen (kreditur) dan pihak debitur yang melakukan kontrak pembiayaan konsumen, dalam situasi saat ini dimana Pandemi covid-19 belum berakhir hendaknya permasalahan wanprestasi dapat diselesaikan secara musyawarah untuk dapat mencapai win-win solution sehingga tercapai kesepakatan yang saling menguntungkan kedua belah pihak.

\section{DAFTAR PUSTAKA}

Dr. Aminah, SH, M. (2020). Pengaruh Pandemi Covid 19 Pada Pelaksanaan Perjanjian. Private Law Review, Vol.7 (1).

Hernoko, A. Y. (2010). Hukum Perjanjian Asas Proporsionalitas Dalam Kontrak Komersial. Prenamedia Group. Jakarta.

Kosasih, J. I. (2019). Kausa Yang Halal dan Kedudukan Bahasa Indonesia dalam Hukum Perjanjian. Sinar Grafika. Jakarta.

Sembiring. (2001). Hukum Dagang. PT. Citra Aditya Bakti. Bandung.

Siombo, M. R., \& Adi, E. A. W. (2020). Implikasi Keppres No.12 Tahun 2020 Pada Perusahaan Pembiayaan. Refleksi Hukum Jurnal Ilmu Hukum, Vol.5 (1).

Sunaryo. (2009). Hukum Lembaga Pembiayaan. Sinar Grafika. Jakarta.

Sunggono, B. (2015). Metodologi Penelitian Hukum. Rajawali Pers. Jakarta.

Subekti. (2002). Hukum Perjanjian. PT. Intermasa. Jakarta.

Sutarjo, A. Y., \& Djuwityastuti. (2018). Akibat Hukum Debitur Wanprestasi pada Perjanjian Pembiayaan Konsumen dengan Obyek Jaminan Fidusia yang Disita. Privat Law, Vol. 6(1).

Syaifuddin, M. (2012). Hukum Kontrak Memahami Kontrak dalam Perspektif Filsafat, Teori, Dogmatik, dan Praktik Hukum (Seri Pengayaan Hukum Perikatan). Mandar Maju. Bandung. 